Jurnal Ilmial

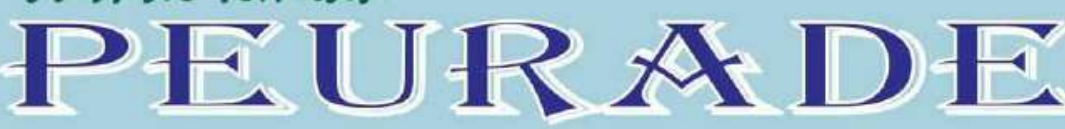

Vol. 5, No. 1, January 2017

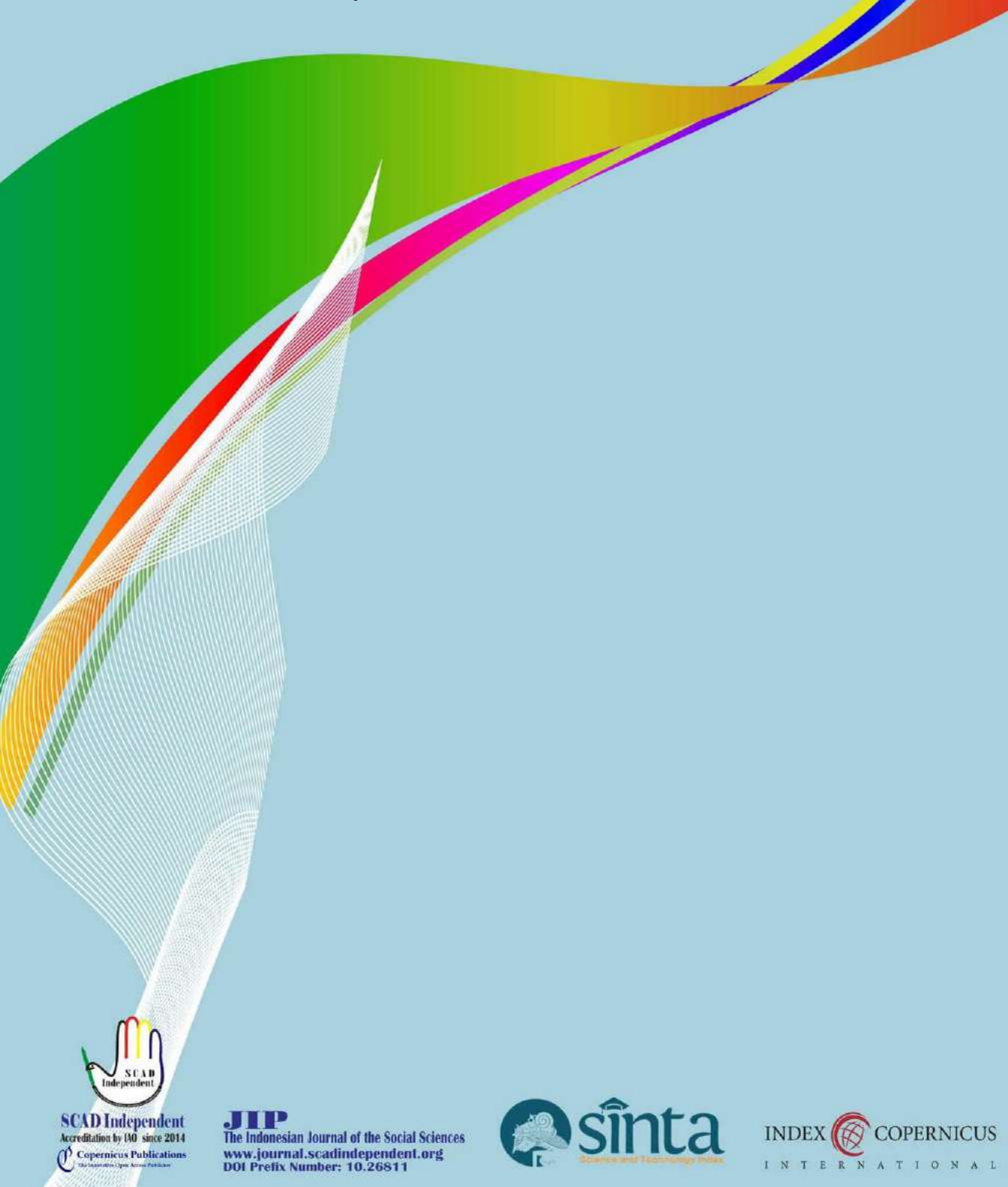




\title{
DEVELOPING AN ENGLISH EDUCATION DEPARTMENT CURRICULUM
}

\author{
Habiburrahim \\ Ar-Raniry State Islamic University, Indonesia \\ Contibutor Email: habib.habiburrahim@fulbrightmail.org
}

Received: Oct 21, 2016

Accepted: Nov 7, 2016

Published: Jan 28, 2017

Article Url: http://journal.scadindependent.org/index.php/jipeuradeun/article/view/114

\begin{abstract}
Curriculum is the heart of teaching and learning program. Through a curriculum, teachers formulate the designated learning objectives and their outcomes and transform all those formulated goals to students. This paper has an attempt to elaborate significant information and models on curriculum that could be developed at the English Education Department (PBI - Pendidikan Bahasa Inggris) of Ar-Raniry State Islamic University (UIN Ar-Raniry) Darussalam, Banda Aceh as an Islamic higher education institution. The paper reviews various literatures on language learning curriculum, teaching English as a foreign language curriculum, and professional learning curriculum. The paper also analyses the 2016/2017 UIN Ar-Raniry manual/handbook, and the 2015 annual report of the PBI department curriculum monitoring and evaluation (Monev). The findings elucidate that the PBI department curriculum has met a standardized curriculum quality. Yet, some weaknesses that could decelerate the language acquisition process are still found in such the PBI department curriculum.
\end{abstract}

Keywords: Curriculum, curriculum design and development, Islamic higher education 


\section{A. Introduction}

The objective of this paper is to provide an overview of a specific curriculum focus that could be developed by the English Education Department (PBI - Pendidikan Bahasa Inggris) of Ar-Raniry State Islamic University (UIN ArRaniry), Darussalam Banda Aceh. Even though UIN Ar-Raniry and PBI department are under the management of the Ministry of Religious Affairs (MoRA), the PBI department also trains students to become English teachers who might teach at general schools, which are under the management of the Ministry of National Education (MoNE). Students who graduate from PBI department are expected to master not only general discipline knowledge of English, but also pedagogy, religious-focused education, and generic employability capabilities. Educational research has generated a body of knowledge to underpin each of these spheres of the curriculum.

A specific curriculum framework at PBI department context is discussed. The framework encompasses a language-learning curriculum, teaching English as a foreign language curriculum, and professional learning curriculum. The primary goal of discussing these curricula is to highlight the significance of each curriculum context that suits particular teaching and learning objectives, particularly those which suit the PBI department. For example, the theories of language learning curriculum and teaching English as a foreign language curriculum have different approaches and concepts. An important factor in a language-learning curriculum is to consider its general learning purpose. Students may study English for a qualification or an English degree. In contrast, the curriculum for teaching English as a foreign language is designed specifically to prepare and train students to become English elementary and secondary school teachers. Hence, most programs deal with pedagogical issues such as teaching methodology, course design and development, and leadership in teaching, as well as assessment.

\section{B. Language learning curriculum}

This part of the paper relates to how the curriculum may be adjusted to meet students' language learning objectives. The motives for learning a foreign language vary among people; some may study it for academic purposes and 
others may learn it for career-oriented considerations. Development of language learning curriculum must consider the factors that inspire someone to study a foreign language. Those factors are regarded as a significant platform to guide curriculum developers in constructing a curriculum that meets its constituents' learning objectives.

The significant literature in the area of language learning has a clear message; beliefs and motivations play a critical role in learning a language (Aragao, 2011; Bernat \& Gvozdenko, 2005; Mohebi \& Khodadady, 2011; Oakes, 2013; Purdie \& Oliver, 1999; Wong, 2010). Bernat and Gvozdenko (2005) note that perceptions, attitudes, beliefs, and expectations are significant influences in driving language learners to succeed in learning English as a foreign language.

In a similar vein, Wong (2010) notes that language learners having strong self-efficacy and motivation to succeed in learning are more likely to put more effort into successfully accomplishing their learning objectives, even when the shadow of failure hangs over them. In contrast, learners who are less motivated, or who are doubtful in perceiving their ability to succeed, are more likely to put less effort into learning, and often tend to give up easily when they encounter a learning challenge. Wong argues that "...successful learners develop insightful beliefs about the language learning process, their own abilities, and the use of effective learning strategies which have enhanced their performance in language acquisition" (p. 124). She adds that learners may also have misconceptions or negative beliefs about learning a foreign language, resulting in a demotivated attitude towards a learning objective. For example, a student who believes someone should not speak English if they cannot speak well will not practice it. In contrast, a student who does not have any negative beliefs about English will start practicing and repeating it a lot, resulting in acceleration of language acquisition.

According to Aragao (2011), self-confidence or self-esteem may always contribute to the students' willingness to practice English with their teachers, peers, and surrounding community. Aragao (2011: 304) notes that: 
Emotions like shyness, embarrassment, pride, self-esteem, inhibition can be related to beliefs one has about oneself and the surrounding environment, such as the fear of feeling embarrassed when speaking in class may be due to a belief that a classmate will criticize or laugh at the student's performance. Self-conscious emotions come with experience and with the emergence of certain beliefs about one's relationship to the foreign language classroom.

Research into Beliefs about language learning for Malaysian pre-service teachers carried out in Malaysia reveals that the primary objective of learning English as a foreign language is its utility value, namely to better understand English and to find a better career opportunity (Wong, 2010). Wong concludes that learners' beliefs in learning a foreign language are situational and dynamic, depending very much upon their interest in learning a foreign language, especially English. To this end, she suggests that educators should pay particular attention to students' awareness and beliefs about language learning. This language-learning objective seems applicable to other Asian countries, and Indonesia is no exception. In Aceh, most students tend to study English so they can communicate well in it and get a better job at multinational companies and other bona fide national enterprises (UNDP, 2016).

Since motivation, attitudes, beliefs, and expectations about language learning have been identified as affecting learning and outcomes, the language learning curriculum and its instruction can be developed to clearly address diverse students' particular study needs. In the context of an Islamic higher education institution, particularly in Aceh with its majority Muslim population, English language learning can also be associated with the knowledge seeking orientation (to search for Islamic-related information written in English) and to seek better job opportunities. The PBI department curriculum could accommodate students' interest in learning English to enrich their understanding of Islamic scholarship.

\section{Teaching English as a foreign language}

This part of the paper describes how the curriculum may be adjusted so that students can master the knowledge, attitudes, and pedagogical skills 
to function in teaching English as a second language after they have finished their study at PBI department of UIN Ar-Raniry. The PBI department's primary objective is to teach and prepare students to be English teachers. It is expected that after students have graduated from this department, they will have sufficient English and pedagogical skills to teach at elementary or secondary schools. This expectation has been documented in the 2016/2017 UIN Ar-Raniry manual/handbook regarding the academic issues.

It has long been agreed that many factors may profoundly influence second language acquisition. According to Whyte (2011), factors include the frequency of language exposure that learners experience, the volume of their interaction and engagement with the targeted language, and the quality or frequency of constructive feedback they receive from their teachers or tutors. Whyte, therefore, suggests that to accelerate the second language acquisition process, the language curriculum and syllabus could be developed to enable learners to access rich language input, participate in active group discussions, and receive individualised instruction. She also strongly urges teachers and tutors to get involved actively in mentoring their students through using the targeted language as often as possible.

However, according to Oxford (2002), applying the above approaches might not guarantee that students will easily succeed in foreign language learning because successful language learning is also influenced by students' individual learning styles and strategies. Oxford argues that “...successful learners often use metacognitive strategies such as organizing, evaluating, and planning their learning" (p. 125). Brown, Bransford, Ferrara, and Campione (1983), cited in Oxford (2002), say that "...use of those metacognitive behaviours - along with cognitive strategies such as analysing, reasoning, transferring information, taking notes, and summarising - might be considered part of any definition of truly effective learning" (p. 125).

In addition to Whyte and Oxford's ideas regarding factors that may stimulate language acquisition, research has also documented that language immersion programs play a critical role in accelerating English language skills mastery (Baus, Costa, \& Carreiras, 2013; Gebauer, Zaunbauer, \& Moller, 2013; Lee, 2009; Tang, 2011). According to Gebauer et al. (2013), there is a 
positive correlation between language development and foreign language immersion. He concludes that adequate language exposure, or having authentic language learning opportunities, increases students' motivation to study English, and at the same time quicken its acquisition.

In the search for an English language curriculum, White (1988, cited in Hadley, 1998) says that an ESL curriculum or syllabus is commonly classified into two categories; type " $A$ " and type " $B$ ". The type " $A$ " syllabus focuses on what students should learn in classrooms, with an emphasis on subject and content. The teaching and learning is centred on teachers, and the teachers have supreme authority over how the class and course are managed. The type " $\mathrm{B}$ " syllabus, in contrast, focuses on how ESL should be learned. The emphasis of this type of syllabus is on the teaching and learning process, in which learning objectives are formulated based on students' needs. The objective of providing language courses more relevant to learners' needs has also been proposed by Richards (2001). As a result, teachers and students work to design a study and testing format, in which the focus of study can accommodate students' learning objectives and expectations.

In the last ten years, researches have revealed that content-based instruction and project work have been used extensively to promote students' engagement in language learning (Boud \& Costley, 2007; Iakovos, Iosif, \& Areti, 2011; Stoller, 1997, 2002), suggesting that contentbased instruction could lead students to develop language skills and become more knowledgeable individuals. Stoller (2002) states that “...by integrating project work into content-based classrooms, educators create vibrant learning environments that require active student involvement, stimulate higher-level thinking skills, and give students responsibility for their own learning" (Stoller, 2002, p. 107). The outcome of project-based learning (PBL) might also provide an opportunity to develop and build students' multiple skills, which will be useful for their future career and social life (Boud, 2012; Erben, Ban, \& Castaneda, 2008). Thus, integrating the development of wider curriculum objectives is a common process.

It is equally important to note that according to Stoller (1997), cited in Iakovos (2011), strength of the content-based curriculum or syllabus is 
that "it lends itself to the natural teaching of the four language skills" (Iakovos, et al., 2011: 115). For example, according to Iakovos, within the content-based instruction context students are urged to read original reading materials to interpret, comprehend, analyse, and understand any information provided so they can respond either orally or in writing. Undoubtedly, such a learning approach normally involves writing, followed by listening and reading. When students apply these four language skills in reading a text in the formal learning context, it is possible to master four significant English language skills.

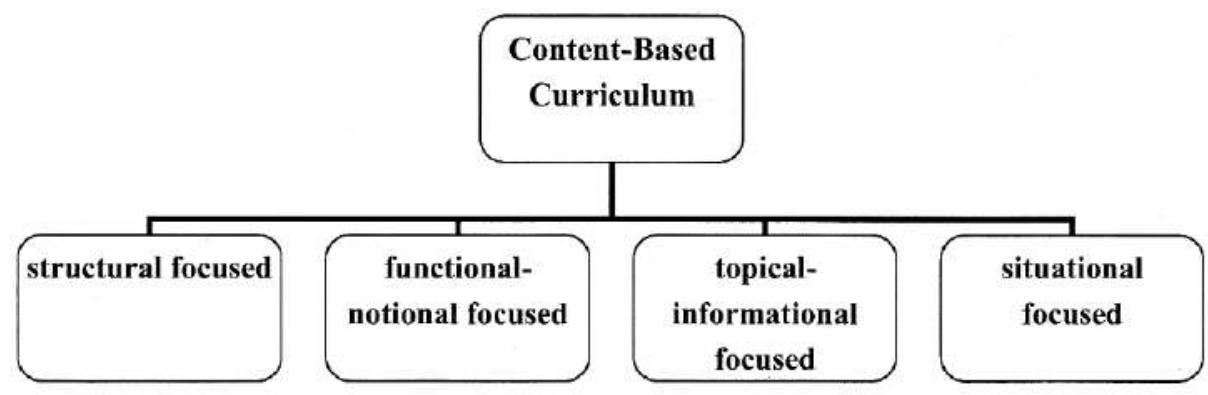

Figure 1: Content-based curriculum model

Adopted from Tang (2011) modified by Hadley (1988).

According to Tang (2011), the four-language teaching skills model above (Figure 1) emphasises a different focus. The traditional structural focused model divides English into several elements. As such, the intention of mastering the language is to study its particular elements, such as phonological aspects, lexical concepts, and grammatical context, and its operational system. As a result, courses are commonly developed based on a structural orientation encompassing the four English language skills of listening, reading, writing, and speaking.

Tang notes that the functional national focused model regards English as a means of functional expression, in which English is regarded as a language of communication. English learning in this learning mode emphasises the semantic and communicative domains rather than grammatical aspects. Therefore, a course is designed to meet the national objectives, via the use of English, in academic, cultural, and social contexts. 


\section{Professional learning}

This section of the paper relates to how the curriculum may be adjusted so that students can master the knowledge, skills, and attitudes to function in the workplace upon completion of their study at this department. The PBI Department is mandated to train students to be professional English teachers. It has a responsibility to ensure that students have mastered adequate skills to become professional teachers and that they are able to perform their tasks professionally.

Education based on the concept of teaching as a profession has been promoted over the last twenty years (Darling-Hammond, 2010). According to Darling-Hammond, teachers must be able to assist students to learn in such a way as to develop their higher-order thinking and performance skills. She notes that several efforts have been made to reach this professional learning (PL) objective. Similarly, several programs have been implemented successfully, including fostering a strong relationship with schools and other learning institutions. In preparing students to learn more professionally, Darling-Hammond (2010) states that students should be active in understanding the pedagogical aspects, and curriculum should encourage students to engage deeply in the learning process.

Indeed, Darling-Hammond's ideas have influenced our understanding of the ongoing curriculum development process that is attuned to the concept of professional teaching. Accordingly, it is commonly agreed that in teacher education programs, curriculum should focus on students' development as novice professionals.

In Australia, three domains of attributes and standards have been formulated for teacher educators. They are: (1) professional knowledge; (2) professional practice; and (3) professional engagement (Australian Institute for Teaching and School Leadership (AITSL), 2016). Each domain covers significant knowledge and skills that teacher educators must master. Under the professional knowledge domain, for example, teacher educators must be able to identify their students and their learning approach, and must master the teaching materials and know how to teach. The foci of teaching in this 
area cover differentiating teaching to meet students' diverse learning needs, content selection and organisation, and curriculum evaluation and reporting. Under the professional practice domain, in addition, the foci of student educators' development are on planning and implementing effective teaching and learning, creating and maintaining supportive and safe learning environments, and assessing and reporting students' learning progress. Meanwhile, the professional engagement domain emphasises engagement in professional learning and self-dedication towards the teaching tasks, including engaging professionally with colleagues, parents/carers, and the surrounding community. Graduates must reach the initial (Graduate Teacher) level across all domains at graduation.

\section{E. Discussion and conclusion}

This paper has provided knowledge and understanding about some curriculum practices, including language learning curriculum, teaching English as a foreign language curriculum, and professional learning curriculum. The review of literature regarding the teaching of English as a foreign language identified factors affecting students' acquisition of a foreign language. First and foremost is the student's objective and motivation for learning English, which may affect their level of engagement in learning, and result in increased language articulation, exposure, and practice. The literature emphasis that this curriculum attempts to enhance students' pedagogical skills including teaching methodology, course design and development, and leadership in teaching and learning, as well as assessment.

Referring to the 2016/2017 UIN Ar-Raniry manual/handbook, such the above skills have been documented well. The book requires the PBI department curriculum to cover students' competences in pedagogical sphere. To fulfil this objective, the PBI department curriculum offers various topics to be studied by students, including various practical programs and internships. Yet, the immersed program and internship to accelerate the language acquisition as suggested by the literature seems to be a minor issue 
in the PBI department curriculum. According to the 2015 annual report on curriculum monitoring and evaluation (Monev) of the PBI department, in most occasions both in formal and informal gathering, either teachers or students at this department still commonly use Bahasa (Indonesian language) as the communication language. This may decelerate the process of students' language acquisition.

As such, there should be a firm rule in the curriculum to strongly emphasis the language immersion at particular stages and circumstances. In terms of internship, in addition, the current PBI department curriculum does not have a broad sphere of internship; it lies only on teaching domain. The PBI department curriculum should encourage and provide opportunities for its students to do internship at various institutions and organizations focussing on various English work related skills.

Besides this internal factor, other external aspects, such as learning strategies and approaches, input and feedback from teachers, were also identified as playing a significant role in accelerating the language acquisition process. The 2015 annual report on curriculum monitoring and evaluation (Monev) of the PBI department elucidates that students' satisfaction on students and lecturers' engagement, students and lecturers' interaction, and lecturers' feedbacks are satisfactory.

Furthermore, with regard to the education and development of teachers, the review has shown that education must be able to develop students' competences in teaching and, accordingly, ways to teach (strategies). As such, student educators not only have to know the pedagogical aspects of their subject, but they must also be able to understand their students' characteristics, to interact with students and parents as well as the community, and make quick and wise decisions in overseeing innovations to improve education quality. Referring to the 2016/2017 UIN Ar-Raniry manual/handbook, and the 2015 annual report, all those components have met a standardized curriculum quality endorsed by both national and local institutional accreditation board. 


\section{Bibliography}

Aragao, R. (2011). Beliefs and emotions in foreign language learning. System, 39, 302-313. doi: 10.1016/j.system.2011.07.003

Australian Institute for Teaching and School Leadership (AITSL). (2016). Australian professional standards for teachers, from http://www.teacherstandards.aitsl.edu.au/CareerStage/Graduat eTeachers/Standards Retrieved on 16/10/2016

Baus, C., Costa, A., \& Carreiras, M. (2013). On the effect of second language immersion on first language production. Acta Psychologica, 142, 402-409. doi: 10.1016/j.actpsy.2013.01.010

Bernat, E., \& Gvozdenko, I. (2005). Beliefs about language learning: Current knowledge, pedagogical implications, and new research directions. Teaching English as a Scond or Foreign Language (TESLEJ), 9(1), 1-21.

Biggs, J. (1999). Teaching for quality learning at university: What the student does. Buckingham: The Society for Research into Higher Education and Open university press.

Boud, D. (2012). Problematising practice-based education. In J. Higgs, R. Barnett, S. Billett, M. Hutchings \& F. Trede (Eds.), Practice-based education: Perspectives and strategies. The Netherlands: Sense Publishers.

Boud, D., \& Costley, C. (2007). From project supervision to advising: New conceptions of the practice. Innovations in Education and Teaching International, 44(2), 119-130. doi: 10.1080/14703290701241034

Boud, D., \& Falchikov, N. (2006). Aligning assessment with long-term learning. Assessment and Evaluation in Higher Education, 31(4), 399413. doi: $10.1080 / 02602930600679050$

Calderhead, J., \& Robson, M. (1991). Images of teaching: Student teachers' early conceptions of classroom practice. Teaching and Teacher Education, 7(1), 1-8.

Chamot, A. U., \& O'Malley, J. M. (1987). The cognitive academic language learning approach: A bridge to the mainstream. TESOL Quarterly, 21(2), 227-249.

Chamot, A. U., \& O'Malley, J. M. (1994). The CALLA handbook: Implementing 
the cognitive academic language learning approach (2nd ed.). Reading, Massachusetts (MA): Addison-Wesley Publishing Company

Danaher, P. A., Tyler, M. A., \& Arden, C. H. (2007). Curriculum leadership, quality and technology in a suite of Australian further education and training teacher education programs: Making meaning, performing practice and constructing new learning futures. International Journal of Pedagogies and Learning, 3(2), 74-83.

Darling-Hammond, L. (2010). Teaching and educational transformation. In A. Hargreaves, A. Lieberman, M. Fullan \& D. Hopkins (Eds.), Second international handbook of educational change. New York: Springer.

Erben, T., Ban, R., \& Castaneda, M. (2008). Teaching English language learners through technology (Teaching English language learners across the curriculum) (1st ed.). New York: Routledge.

Gebauer, S. K., Zaunbauer, A. C. M., \& Moller, J. (2013). Cross-language transfer in English immersion program in Germany: Reading comprehension and reading fluency. Contemporary Educational Psychology 38, 64-74. doi: 10.1016/j.cedpsych.2012.09.002

Gravani, M. N., Hadjileontiadou, S. J., Nikolaidou, G. N., \& Hadjileontiadis, L. J. (2007). Professional learning: A fuzzy logicbased modelling approach. Learning and Instruction, 17, 235-252. doi: 10.1016/j.learninstruc.2007.01.007

Hadley, G. (1998). Returning full circle: A survey of EFL syllabus designs for the new millenium RELC Journal, 29(2), 50-71. doi: $10.1177 / 003368829802900203$

Hammerness, K., Darling-Hammond, L., Bransford, J., Berliner, D., Cochran-Smith, M., McDonald, M., \& Zeichner, K. (2007). How teachers learn and develop. In L. Darling-Hammond \& J. Bransford (Eds.), Preparing teachers for a changing world: What teachers should learn and be able to do (1st ed.). San Francisco, CA: Jossey-Bass.

Iakovos, T., Iosif, F., \& Areti, K. (2011). Content-based instruction in the teaching of English as a foreign language. Review of European Studies, 3(1), 115-121. doi: 10.5539/rev.v3n1p115

Knight, P. (2002). A systematic spproach to professional development: Learning as practice. Teaching and Teacher Education, 18, 229-241. 
Lee, J. F. K. (2009). ESL students' perceptions of a short-term overseas immersion programme. Teaching and Teacher Education 25, 10951104. doi: $10.1016 /$ j.tate.2009.03.004

Marzuki, M. (2016). Diniyyah in Public Schools: A Model of Islamic Curriculum Implementation in Multi Religious Society in Banda Aceh-Indonesia. Jurnal Ilmiah Peuradeun, 4(1), 15-26.

Mohebi, S. G., \& Khodadady, E. (2011). Investigating university students' beliefs about language learning. RELC Journal, 42(3), 291-304. doi: $10.1177 / 0033688211422900$

Nurhasanah, N., \& Nida, Q. (2016). Character Building of Students by Guidance and Counseling Teachers Through Guidance and Counseling Services. Jurnal Ilmiah Peuradeun, 4(1), 65-76.

Oakes, L. (2013). Foreign language learning in a 'monoglot culture': Motivational variables amongst students of French and Spanish at an English university. System, 41, 178-191. doi: 10.1016/j.system.2013.01.019

Oxford, R. L. (2002). Language learning strategies in a Nutshell: Update and ESL suggestions. In J. C. Richards \& W. A. Renandya (Eds.), Methodology in language teaching: An anthology of current practice. New York: Cambridge university press.

Purdie, N., \& Oliver, R. (1999). Language learning strategies used by bilingual school-aged children. System, 27, 375-388.

Retrieved on $7 / 10 / 2016$

Richards, J. C. (2001). Curriculum development in language teaching. New York: Cambridge University Press.

Saifullah. (2015). The Internalization of Democratic Values into Education and Their Relevance to Islamic Education Development (Synthetic, Analytic, and Eclectic Implementation of John Dewey's Thoughts). Advanced Science Letters, Journal of Computational and Theoretical Nanoscience, 21 (7), pp. 2301-2304, DOI: 10.1166/asl.2015.6257

Stoller, F. L. (1997). Project work: A means to promote language content. English Teaching Forum, 35(4), 29-37.

Stoller, F. L. (2002). Project work: A means to promote language and content. In J. C. Richards \& W. A. Renandya (Eds.), Methodology in language teaching: An anthology of current practice. New York: 
Cambridge university press.

Tang, H.-W. V. (2011). Optimizing an immersion ESL curriculum using analytic hierarchy process. Evaluation and Program Planning, 34, 343-352. doi: 10.1016/j.evalprogplan.2011.04.002

Thomas, L., \& Beauchamp, C. (2007). Learning to live well as teachers in a changing world: Insights into developing a professional identity in teacher education. The Journal of Educational Thought 41(3), 229-243.

UNDP (2016). Provincial human development report Aceh 2010, from http://hdr.undp.org/sites/default/files/nhdr_aceh_2010_english.pdf

Usman, M. (2015). Teaching Model of Learning English Writing at University. Jurnal Ilmiah Peuradeun, 3(3), 441-450.

Whyte, S. (2011). Learning theory and technology in university foreign language education: The case of French universities. Arts and Humanities in Higher Education 10(2), 213-234. doi: $10.1177 / 1474022210364783$

Wong, M. S.-L. (2010). Beliefs about language learning: A study of Malaysian pre-service teachers. RELC Journal, 41(2), 123-136. doi: $10.1177 / 0033688210373124$ 